\title{
From Complementarity to Conflict: A Historical Analysis of Farmer- Fulbe Relations in West Africa
}

\author{
Mark Davidheiser and Aniuska M. Luna
}

\begin{abstract}
This paper provides a socio-historical analysis of conflict between Fulbe pastoralists and farmers in Sub-Saharan Africa. The discussion examines various structural factors that have fostered conditions conducive to conflict generation and intensification, including international development projects, demographic changes, and environmental degradation. Our analysis highlights changes in production systems and land tenure regimes as central to the aggravation of farmer-herder goal incompatibility and intercommunal strife. Many of these changes are the deliberate results
\end{abstract}

\footnotetext{
* Mark Davidheiser, Ph.D., is Chair of the multi-institutional Africa Peace and Conflict Network and Assistant Professor of Conflict Resolution and Cultural Anthropology at Nova Southeastern University. His work examines human social responses to crisis, change, and conflict and topics such as reconciliation and peacebuilding. He has conducted field research on mediation in Eritrea, the Navajo and Hopi territories, Senegal, and The Gambia.

Aniuska M. Luna has an M.A. in Cross-disciplinary Studies with Certificates in Conflict Analysis and Resolution. For the past few years she has worked towards her doctoral degree in conflict analysis and resolution and on advocacy issues related to modern day slavery.
} 
of interventions and legislation that were based on Western models and intended to increase production outputs and market integration. Effective conflict mitigation will require the abandonment of top-down, directive policymaking in favour of a more supportive engagement that strives to draw on and build up local resources and capacities.

\section{Introduction}

The Fulbe are an ethno-linguistic group spread across fifteen countries in Africa. ${ }^{1}$ By the year 2000, there were 13 million Fulbe speakers inhabiting an area of over 3000 square miles, from Mauritania in the north to Cameroon in the south, Sudan in the east and Senegal in the west (Miller 2007). Due to their widespread regional distribution, the Fulbe have an extensive history of interaction with a large array of groups, including many whose subsistence is primarily based on horticulture. Fulbe have historically been known as herders. Many do not engage solely in pastoralism and the marketing and exchange of animal products, however. In some areas, Fulbe are known as traders and shopkeepers and for numerous others cultivation has become increasingly significant. Growing numbers of Fulbe have added some horticultural activity to their production strategies; others have adopted farming as their primary mode of subsistence. Nevertheless, the association between Fulbe and herding remains strong in the minds of many Africans, and many contemporary Fulbe are pastoralists.

Although there has always been a mix of conflict and cooperation between pastoralists and horticulturalists, conflict has become increasingly likely due to several historical, social and environmental factors. During the precolonial era, the subsistence and small-surplus peasant modes of production of Fulbe herders and West African farmers were often intertwined in a mutually beneficial fashion. The changes in land tenure laws during the colonial period increased commodity production and the environmental degradation that often results from it. The adoption of new irrigation

1 There are a number of alternate labels for the ethnolinguistic or collective identity category of 'Fulbe', including 'Fula,' 'Fulbe,' 'Peuhl' and 'Pulaar'. 
techniques, and the sedentarisation schemes for transhumant pastoralists that accompanied the introduction of capitalism to West Africa, disrupted the production symbiosis of Fulbe and farmers in addition to increasing the likelihood of conflict between them.

Integrating capitalist and indigenous modes of production undermined the previous symbiosis of the agriculturist and pastoralist production systems. The associated outcomes, (for instance, population growth, environmental degradation, and a gradual shift from exchange-based relations to marketisation and commodification), intensified the pressure on natural resources and made them both more scarce and more desirable. As the production patterns were altered and the scarcity of natural resources and the competition for them increased, there was a corresponding growth in the potential for opposition between the interests of graziers and cultivators.

The international market economy began impacting Africa well before the colonial era, but colonialism heralded an era of unprecedented European expansion into the continent, complete with policymaking and social engineering. Many of the trends begun then continued after independence under the direction of indigenous elites, and assisted by multinational corporations and the development industry. Widespread changes in production systems and socio-political landscapes created conditions that enabled the likelihood of goal incompatibility, and heightened the potential severity of strife between Fulbe herders and their farmer neighbours in West Africa. This assessment implies that conflict mitigation between Fulbe herders and West African farmers requires systemic, institutional, and/or structural changes to address the root causes. The current analysis explores the historical, structural, and various cultural factors that led to the emergence of conflict between these two groups. The paper ends with brief recommendations on what must be done in order to ameliorate it or work towards its resolution. 


\section{Historical overview}

\section{Pre-colonial era}

The pre-colonial West African domestic mode of production was based on subsistence and small surplus production. Fulbe herders generally engaged in transhumance, which was a sustainable or 'ecologically stable' production strategy (Sinclair \& Fryxell 1985:992). Fulbe herders also exchanged some of the animal products they produced with farmers for grain, thus supplementing the diets of each respective group (Wilson 1984).

In 'Desert-Side Economy of the Central Sahel', Lovejoy and Baier (1976) describe how in pre-colonial Niger the connections between pastoralist and agriculturalist groups and production systems meant that farmers and herders each had a stake in the well-being of the opposite group. The interconnectedness of these two modes of production was a common occurrence in pre-colonial West Africa. ${ }^{2}$ Their interdependence, thus, created 'symbiotic relationships' between 'pastoral and settled agricultural systems' based on a certain commonality of interests (World Bank Overseas Evaluation Department 1994:4).

Two intergroup interactional patterns and modalities of exchange historically practised in the Sahel that characterise the complementarity of farming and herding are cattle entrustment and dung and stubble exchanges (Bassett 1988; Galaty \& Johnson 1990; Harshbarger 1995; Picardi \& Seifert 1976). These are mutually beneficial cooperative schemes that increase productivity and reduce famine risk, or risk of loss by local epidemics for both types of producers. Cattle entrustment usually involves some variation on the following theme: A farmer lends cattle that he or she owns to a herder, who will then take care of them in return for being able to keep some or all of the milk and offspring that the cattle produce. The dung and stubble exchanges take place as the Fulbe move from their wet season pastures to the wetter grasslands in which subsistence and small-surplus producing peasant

2 See Baier 1976; Frantz 1975; Fratkin, Roth \& Galvin 1994; Guéye 1994; Mortimore 1989 and Forde 1960 as cited in Van den Brink, Bromley \& Chavas 1995 for further information on this issue. 
farmers have long worked. In dung and stubble exchanges, known as the contrat de furnure in the Francophone Sahel, Fulbe graze their cattle on fields that have already been harvested, and the manure of the cattle provides fertilisation for the farmer (Van den Brink, Bromley \& Chavas 1995).3

The regions to the south of the Fulbe's arid zone wet season grazing lands were essential to the pre-colonial Fulbe production system. These farmerpopulated indigenous areas provided dry season foods and also functioned as drought reserves. The pastoralist production system relied on mobility that was typically transhumant rather than nomadic in nature. Seasonal migration depended on careful timing as Fulbe travelling southwards needed an understanding of agricultural cycles in order to avoid disputes with farmers (Picardi \& Seifert 1976:46).

Some Fulbe groups have created social structures geared towards minimising conflicts with farmers and preserving the overall harmony between these groups that was necessary for their production symbiosis. An example is the role of the Ruga in Niger and Nigeria. The Ruga is an elected official who regulates the grazing and pasture use of his group. He is in charge of selecting migration routes and deciding where specific animals will graze. The Ruga is also considered responsible for internal and external dispute management and settling conflicts between farmers and his group (Ellwood 1995).

Another manifestation of the linkages between Fulbe and farmer societies is the history of elasticity of the ethnic identities of Fulbe and Manya farmers: 'distinctions between Fulbe cattle herders and Manya agriculturalists have been continuously manipulated to permit people to cross the ethnic boundary' (Lovejoy \& Baier 1976:158). Practices like these made it possible for Fulbe to coexist and travel through regions settled by farmers, while

3 Picardi and Seifert (1976) highlight the importance of this delicately timed mobility to the Fulbe production system. Accordingly: A symbiotic relationship is thus established and the herdsmen have customary 'clients' among the agriculturalists to whom they regularly return with their cattle. However, the herdsmen delay the southern portion of their trek until after harvesting to avoid having the cattle wander into unharvested fields, thus incurring the farmers' wrath (Picardi \& Seifert 1976:46). 
maintaining relatively cooperative relations with them and preserving the symbiotic production system that evolved as an adaptive response to the ecology of West Africa.

\section{Colonial period}

Contact and interaction with Europeans were associated with a variety of transforming processes impacting African social and physical landscapes. The level of influence was greatly magnified in colonial settings. The early industrial states of Europe were becoming increasingly modernised, legal-rational, and bureaucratic. Their greatest interest in and capacity for administration encouraged policymaking geared toward the intentional manipulation of African environments for a variety of purposes. For example, by drafting new laws regarding land ownership and using European style court systems, colonial regimes gained control of large amounts of land in West Africa.

Europeans imposed formal laws on societies that had developed generally informal - but often quite sophisticated and complex - systems of land use and tenure that were appropriate for local production styles and tended to incorporate farmer-herder interaction in the production process (Jacobsen 1988). The resulting changes undermined this cooperative system, reduced farmer-Fulbe goal compatibility, and weakened customary or informal land tenure and resource use. This is significant because such systems contain culturally specific and relevant procedures and mechanisms for dispute management (Lane 1996; Shepherd 1996). One of the many unintended outcomes of the resultant state policies, ergo, was an array of structural conditions conducive to intergroup conflict between sowers and graziers.

Key aspects of the subsumption of land by capitalism were the policies and projects that aimed for the privatisation and nationalisation of land and sedentarisation of Fulbe nomads. Flexible property rights had been an important historic adaptive strategy in the Sahel, especially for Fulbe (Waller \& Sobania 1994). They played a significant role in the sustainable use of natural resources and in preventing farmer-herder goal incompatibility and conflict. As part of the subsumption of the forces of production, the 
colonial regimes pursued policies of privatisation. These policies not only reduced indigenous peoples' control of and access to land and natural resources, (thus making them more scarce and increasing competition and conflict over the resources that were still available), but privatisation was also associated with environmental degradation. As noted by Van den Brink, Bromley and Chavas (1995:392), 'exclusive property regimes' have repeatedly resulted in the 'overuse of the resource base, amplification of negative effects of drought periods, and increased conflicts between nomads and farmers, among nomadic groups, and within nomadic groups'.

Nationalisation of land, on the other hand, not only occurred during the colonial era but it has continued under post-colonial governments. Such policies have often thrown traditional land tenure systems and relations of production into disarray, and caused herders to seek new land for grazing and increase the size of their herds. The nationalisation of land was especially hard on pastoralists as colonial regimes tended to lay claims to territories that were not permanently settled, and that were an important part of the transhumant Fulbe production system.

Transient populations are anathema to the legal, rational, and bureaucratic state. Attempts to sedentarise nomadic and transhumant herders are another policy pursued by colonial regimes in West African that continues to this day. Ethnocentrism and the belief that sedentarised herders are easier to tax and regulate can account for part of this phenomenon, but the desire of capitalist forces to gain control of land also played a role. In addition, sedentarisation enables the surveillance and control of nomads.

Settled, stationary groups typically mistrust nomads, who are often viewed as threatening. They can be stigmatised as thieves (as exemplified in the case of the Turkana, the Roma 'Gypsies', and the Lapps of Finland) or as warlike. ${ }^{4}$ Once herders were permanently settled in a certain area it became much easier for colonial regimes to claim the former grazing lands that they utilised. Unfortunately, just as sedentarisation, 'semisedentarization

4 In a North American case of farmer-herder conflict, for instance, there is a long history of juxtaposing stereotypes of aggressive Navajo against peaceful Hopi. 
[of nomads] has serious long-term management and environmental implications which have in turn created another stereotype: the "destructive pastoralist" responsible for the tragedy of the commons' (Waller \& Sobania 1994:50). Such environmental damage further augments the possibility of goal incompatibility and conflict with farmers. As noted by Unruh (1990:224), 'land use conflicts in river basin and floodplain areas increase as degradation of rangelands, growing populations, and greater pressures on these areas to produce food, cause increased competition for land and water resources'.

The sedentarisation of some Fulbe, combined with the other changes in land tenure that colonial regimes undertook, weakened their transhumant production system and the symbiosis with farmers. Sedentarisation, therefore, not only contributed to conflict between these groups but hindered mobility which, in many ecological zones, is greatly beneficial for pastoralist production strategies (Gilles \& Gefu 1990).

Another effect of the capitalist system on production was an increase in commodity production, especially in the agricultural sector. Colonial regimes encouraged - and in various instances imposed - production of cash crops such as cotton. These cash crops were grown for export to the industries of Western Europe. But according to Waller and Sobania (1994:45), 'by 1950 ... pastoralists had been relegated to the periphery of an economic and political system that was now dominated by the needs of export agriculture and in which stock had been bypassed for new avenues of accumulation'. The unsustainable ways in which cash crop farming is conducted caused significant environmental damage and increased desertification. The enormous demand in the world market for the raw materials that were and are grown in West Africa generated an expansion and intensification of farming, frequently resulting in deforestation and the destruction of grazing reserves used by Fulbe in times of drought. For example, in Senegal, Mali and Niger the introduction of new varieties of groundnuts made it possible for farmers to expand to the northern arid regions traditionally used as grazing lands (Sinclair \& Fryxell 1985). 
The switch in production meant major changes in the way that land in West Africa is utilised, and played a major role in the increased land and natural resource competition between the Fulbe and agriculturalists of recent years. Colonialism began a process of increased incorporation into the international markets and exchange network. In this context, production for subsistence came to be seen as inadequate, and customary or traditional forms of land tenure and resource management were considered primitive and outdated (Galaty 1994). Conflict and goal incompatibility between Fulbe and farmers were further exacerbated directly and indirectly by changes in power dynamics, medical advances introduced by Europeans, and demographics.

The colonial governments obliterated the existing political systems, which maintained Fulbe-farmer production symbiosis. These regimes tended to favour certain ethnic groups at the expense of others, and there was a general preference for farming groups, with pastoralists often being stigmatised as unruly and warlike. Consequently, such favouritism caused significant changes in the balance of power between them. This dynamic was an important part in the gradual decrease of available land for Fulbe pastoralist production:

The more rapid incorporation of farming peoples into the developing larger political systems resulted in decreasing control of land and cattle among the pastoralists - this, at a time when rapid growth in the agricultural, commercial, and industrial sectors had generated a larger volume of competition and conflict over basic natural resources (Frantz 1975:14).

Since each collectivity attempts to secure the most resources and benefits for itself, rather than sharing them with others, the existing power structures of cooperation and goal compatibility (such as those in 'peasant-nomad interaction') are challenged (Bates 1971:116). In other words, the processes and changes in power balances between these groups brought about by the colonial administrations altered the cooperative system and generated farmer-herder goal incompatibility and conflict. 
The colonial era further undermined the basis of farmer-Fulbe goal compatibility and the customary land tenure systems, which contained conflict management mechanisms, by introducing systems of conflict management based on formal European-style laws and courts which were ineffective. The Fulbe usually did not use the formal judicial arenas and procedures for handling resource conflicts established by colonial regimes (Frantz 1975:12). This group felt that they would probably not be satisfied with the outcome of judiciary procedures and preferred to migrate, or simply avoided the situation or dispute (Frantz 1975:12).

Prior to the colonial period, 'competition and conflict between these groups [Fulbe-farmers] were often limited because of small human population pressures, periodic droughts, and epidemics of cattle disease' (Frantz 1975:9). Colonialism brought new medical knowledge and practices to West Africa and both the human and the cattle (especially as rinderpest was brought under control) populations rose greatly, resulting in an increase in competition for resources (Ellis \& Swift 1988; Jacobsen 1988). Therefore, 'both the tenure systems imported from Europe to Africa and the reduced mortality rates which have resulted from various pre- and post-colonial health initiatives have impacted heavily on the relationship of Africans to land. Although the former was a deliberate and the latter an accidental factor in changing this relationship, both have increased the potential for conflict' (Shepherd 1996:2). In addition, 'modern' medical services have been used as an additional rationale for the sedentarisation of nomadic Fulbe (and other nomads). The argument is that nomads need to be sedentarised in order to receive proper health care and other 'modern' government services (Ellwood 1995).

\section{Post-colonial period}

After independence, the articulation of the modes of production continued and many of the other processes such as urbanisation, demographic pressure, and increased influence of a global market economy continued, decreasing available pasture land and increasing competition for natural resources in West Africa (Wilson 1984). The models of the colonial era were generally 
followed by post-colonial governments. For example, some of the features of the land tenure systems and land laws (including the bias against pastoralists and nomads) instituted during the colonial period generally remained unchanged (Elbow \& Rochegude 1989). The independent governments and development agencies continued several of the policies instituted by previous regimes such as nationalisation and privatisation of land, sedentarisation of nomads (the desire of the new independent governments to prevent herders from travelling over national borders also played a role in this), the establishment of plantations and encouragement of cash crop production.

Development agencies play a major role in the continuation of a number of the policies and processes begun in the colonial era. After colonialism, development groups, in conjunction with independent governments, have continued the articulation of the two modes of production and the impacts on farming and pastoral systems that increased the likelihood of conflict between farmers and herders. Development in the Sahel has been driven to a large extent by Western agencies that ascribe to the paradigm of formalist economics. The paradigm for development projects in this region has long been influenced by theories of the type that Garret Hardin (1968) presented in the famous article 'The Tragedy of the Commons'. According to Garrett Hardin's (1968) model of land use, common land meant open access land which individual pastoralists could use, unfettered by the constraints of substantive rationality. Privatisation was therefore a way in which the land could be used in a more sustainable manner. This conclusion turned out to be erroneous, but it does fit nicely with the land tenure and free-market capitalist economic system of most Western countries. Since the dominant paradigm for African development linked common property regimes and nomadism to resource degradation, sedentarisation of pastoralists, and the privatisation of land have been dominant features of West African development programs (Galaty 1994; Gilles \& Gefu 1990). The mixture of formalist economics, rational choice models, and equilibrium-based rangeland management theory that has guided the paradigms for development in this region has also meant a continuation of policies that undermine farmer-herder goal complementarity and cause environmental degradation. 
Development agencies have been instrumental in the introduction of new irrigation technology and the drilling of boreholes in West Africa. In much of the Sahel and the neighbouring lands, the arid climate has historically been a key limiting factor in the availability of land for farming. The aridity of such areas has meant that farming, as it was traditionally conducted before colonialism, was not a viable strategy on many areas. In the past, such land was used by the Fulbe for their wet season herding and they would migrate to the wetter zones in the dry season after the farmers there had harvested their crops.

The introduction of new irrigation technology and techniques into Africa through development projects allows the expansion of agriculture into relatively arid regions. In the 1950s and 1960s many farmers in the Sahel expanded north into semi-arid regions traditionally used by Fulbe as grazing lands, and this process has continued since then (Sinclair \& Fryxell 1985). The European bias against nomadism and common property land tenure systems is one reason that farmers have been encouraged by colonial regimes, postcolonial governments, and development agencies to expand into areas used by pastoralists (Frantz 1975). The influence of the tragedy of the commons paradigm and its precursors allowed colonial regimes to justify encouraging farmers to move into former grazing lands and reserves, and produce cash crops by arguing that these were unproductive or unoccupied areas that farmers could settle and plant. The expansion of farmers onto grazing lands remains one major contributor to a frequently noted phenomenon of the late nineteenth and twentieth century: 'a declining resource base for pastoralism' (Bassett 1988:453). This has been one important push factor encouraging Fulbe expansion into southern areas that lack a history of farmer-herder production integration. In addition, irrigation technology played a role in the sedentarisation of pastoralists. As development agencies helped drill new boreholes in the Sahel, pastoralists were encouraged to settle around them (Sinclair \& Fryxell 1985).

Contemporary climatic conditions and patterns have also interacted with rapid population increases, changes in modes of production and increased goal incompatibility and incidences of farmer-herder conflict, especially in 
Africa. Since the 1970s 'there has been a significant decline in the average rainfall received across the African arid and semiarid zone' (Galaty 1994:187, cf Bonfiglioli 1992). These weather patterns are definitely linked to the changes in land tenure and the domestic modes of production in West Africa, and the effects that this has had on the environment. Many theorists have noted the environmental degradation, rangeland defoliation, and deforestation that occurred in West Africa as a result of cash crop production, agricultural strategies emphasising short-term gains and extraction from the land, the drilling of boreholes and sedentarisation of nomads, the move away from customary land tenure systems, and privatisation and nationalisation of land. The end result of these processes is a continent-wide trend towards aridity in which the environment is moving towards 'a new stable state of self-perpetuating drought' (Sinclair \& Fryxell 1985:992). Furthermore, environmental degradation has been explicitly linked by many theorists to development intervention due to the effects of this intervention on population growth, overgrazing, desertification, and unsustainable agricultural projects (Sinclair \& Fryxell 1995). As noted by Ellis and Swift (1988:451), 'in many cases development has exacerbated degradation in pastoral ecosystems... while curtailment of nomadism, losses of grazing lands to agriculture, security problems, and the settlement of some pastoralists have combined to reduce the area of rangeland'.

It is important to note the effects that this weather pattern is having on Fulbe migration. The increasing aridity in the Sahel and decrease in rangeland vegetation mean that natural resources are increasingly scarce and access to them is more likely to be contested. The unusually dry weather pattern of the past few decades (especially the severe drought in the Sahel during the early 1970s) contributed to the southward migration of the Fulbe into more humid zones (Bassett 1988). Fulbe 'out-migration' from the Sahel helped 'crowd already overextended agricultural land in the Sudan zone' (Picardi \& Seifert 1976:51). Their southward migration created new frictions with farmers as the Fulbe moved into more humid areas long dominated by horticultural production. The entry of Fulbe herds in these regions led to crop and soil damage, intergroup competition for natural resources, and 
numerous disputes in localities lacking a history of farmer and herder production symbiosis and interaction and corresponding social institutions for managing conflicts (Basset 1988; Behnke \& Scones 1992; Harshbarger 1995).

A number of other factors are also involved in the massive population flow to the south. There has long been stiff competition for land and water between farmers and Fulbe in the transition zones between pastureland and farmland. The recent northwards movement of farmers combined with additional elements such as demographic pressures and desertification to act as push factors causing Fulbe herders to seek new areas to pasture their herds (Wilson 1984). The combination of the 'declining resource base for pastoralism' in areas long inhabited by Fulbe, and the dry weather patterns in the Sahel weakened the checks on traditional Fulbe southward migration patterns (Gallais 1979; Hjort 1982 cited in Bassett 1988:453). As previously mentioned, these checks promote synergistic and harmonious relations with farmers and avoid conflict over crop damages. For example, poor pasture conditions in Niger and Mali have caused herders there to bring their animals to Burkina Faso, straining Burkina's pasture resources. Areas where water is available are particularly subject to overgrazing. The increasing use of traditional pasturelands for crop production - particularly along the border with Mali - has aggravated the situation and has led to increasing conflict between agriculturalists and pastoralists (USAID 1996).

In other cases, governments of countries like the Ivory Cost and the Central African Republic that want to lessen beef imports and strengthen local food production have supplied and are supplying pull factors for this new southward surge of Fulbe herders. The southerly movement of herders has important implications for the environmental future of the more humid zones. The sandy soil of the arid zones is more resistant to negative impacts from grazing than the heavily textured and clay type soils in the more humid areas (Behnke \& Scones 1992). The southwards migration of Fulbe herders may therefore pose major risks for the long-term health of the southern environments that they are moving to. By examining specific localised cases of farmer-Fulbe interaction, such as those in the next section, one can 
achieve a greater and more concrete understanding of the types of processes described in this paper.

\section{Specific cases}

\section{The Zamfara Reserve district of Nigeria}

This district is located in northwestern Nigeria and was designated as a forest reserve by the British in 1916. Although subsequent legislation prohibited both grazing and farming within the district, arable crop production slowly began to occur there. In 1960 (the year that Nigeria became independent), the district was designated as a grazing reserve. The area is now inhabited by Hausa farmers, settled agro-pastoral Fulbe, and transhumant pastoral Fulbe.

The Zamfara Reserve has become an important rainy season pasture for the herds of Fulbe and pastoralists who have been pushed out from other rangelands. The 'cattle corridors' that Fulbe used to move their herds around according to environmental conditions have either been swallowed up by the expansion of cultivation or have become too narrow for Fulbe herds (Hoffman 1996:5). Government-constructed dams have also reduced the amount of land available to the herders.

The fact that the Zamfara district is an official grazing reserve further contributes to its use by Fulbe. The land tenure laws of Nigeria are very unfavourable to traditional pastoralists and they hold no legal rights over land. They can merely be granted temporary use permits of certain land (Gefu 1992 cited in Hoffman 1996). In addition, ecological pressure on other areas has increased the use of the reserve and, consequently, generated significant overgrazing and environmental degradation. Much of the degradation has been caused by 'government interventions in the indigenous livestock sector... based on certain assumptions that date back to the colonial era' (Hoffman 1996:6).

Land use conflicts between Hausa farmers and Fulbe herders have become common there due to the end of the past pattern of production symbiosis 
between the groups: 'the different ethnic groups and lifestyles are a source for conflicts, particularly since the complementarity between cropping and herding is breaking down: Fulbe become increasingly settled and require crop land without giving up their herds, while Hausa agriculturalists depend increasingly on their own livestock for utilising crop residues and manuring their fields' (Hoffman 1996:1-2). Other factors that have changed the local Fulbe mode of production are the practice of waged herding and the increase in absentee herd ownership. This region in Nigeria provides an example of the environmental degradation, reduction of farmer-herder symbiosis, and increased conflict between Fulbe and farmers that have become common in West Africa.

\section{Senegal}

Groundnuts (peanuts) are an example of a crop grown for export, introduced by the French and promoted by post-independence governments (Freudenberger 1995; Lovejoy \& Baier 1976). Peanut farming in Senegal is often done in an unsustainable way that uses up the fertility of land and contributes to the scarcity of arable land. The groundnut plants are uprooted at harvest time, leaving the ground bare and without any leftover plant material to break down and enrich the soil or groundcover to protect from erosion throughout the dry season. During the latter, the harmattan winds from the Sahara easily blow away the topsoil (Freudenberger 1995). The resulting resource scarcity exacerbates competition between farmers and pastoralists (Traore \& Lo 1996).

The change from subsistence production to commodity production, and the new technology and methods for irrigation, have further encouraged farmer expansion into areas previously used as pastures for the production of other commodities for the international market (Freudenberger 1995; Guéye 1994). In addition, development projects play a role in farmers being 'tempted into lands previously considered too dry for agriculture. Each year new fields are cleared around the boreholes, blocking access routes used by cattle as they move from one grazing area to another and creating bitter conflicts between herders and farmers' (Freudenberger 1995:16). For 
instance, two dams were built along the Senegal River in the 1980s and this caused the displacement of the Fulbe who lived along the banks of the river as well as from other nearby land which previously could not be irrigated. Such land was quickly claimed by wealthy farmers (Freudenberger 1995).

Environmental degradation and pressure placed upon Fulbe herders in Senegal encouraged Fulbe migration patterns into new areas such as the Ivory Coast and Cameroon. Deviating from their historical routes and caution not to damage crops and avoid conflict with farmers, the herdsmen of the Sahel (Fulbe and Tuareg) have thus been forced into territories and humid zones to the South. This migration has generated other cases of farmer-herder conflict as discussed further below.

Freundenberger's (1995) case study of the Ferlo region of northern Senegal, reveals how the post-colonial trend towards sedentarisation, export-oriented cash crop production and the resulting environmental degradation, the expansion of farmers into grazing land and forest reserves, and population increases are leading to JeerinkooBe Fulbe-farmer conflict. The Ferlo region described by Freudenberger (1995) is an area of sparse and extremely variable rainfallwhere'onehamletmayreceiveadrenchingdownpourwhileanotherfive kilometers away remains bone dry' (Freudenberger 1995, 15). The key to the success of the Fulbe in exploiting this environment has been their transhumance (Freudenberger 1995). When the whole Ferlo region is stricken with drought, the Fulbe move south into densely populated areas inhabited by Wolof and Serere farmers. The Fulbe avoid conflicts and find grazing land for their herds by seeking out the forest reserves of this region where farming is not allowed.

The Fulbe's room to manoeuvre in the Ferlo is being restricted on several sides. As population pressure in the south builds and land there becomes more degraded, farmers are increasingly moving into this arid land and are utilising new irrigation technology and boreholes for farming. To the north of the Ferlo are the dams built in the 1980s on the Senegal which have brought farmers into that region. To the west the land has been walled to serve as gardens for absentee owners: 'lush gardens are owned by powerful 
religious leaders, Lebanese businessmen, and other members of an elite based in the capital, Dakar. They serve both wealthy city dwellers and Europe's insatiable desire for fresh fruit and vegetables in winter' (Freudenberger 1995:16). To the south of the Ferlo lie the important forest reserves. The last major reserve, the Mbegué forest, has largely been planted with peanuts by the Mouride Islamic Brotherhood which received a government grant for this. Only three of the thirty-five watering holes are still available for use by the Fulbe. One consequence of the pressure on Fulbe herders in the Ferlo is that some herders have left this region in a phenomenon referred to as 'escape mobility' (Hoffman 1996:10).

Another analysis of the gradual increase in intercommunal conflict is supplied by Guéye's (1994) 'Conflicts and alliances between farmers and herders: A Case Study of the 'Goll' of Fandéne village, Senegal'. The author debunks the notion that farmer-herder coexistence inevitably leads to conflict. In precolonial central Senegal farmer-herder complementarity was 'the rule rather than the exception'. 'Herder and field are natural allies' is a popular saying in this region (Guéye 1994:1). In fact, the Fulbe came to settle in the arid Goll area of the village territories following an invitation from local Serere farmers wishing to maintain their claim to that fallow land by preventing other farmers or agri-business investors from occupying or purchasing it.

A boom in Borassus palm cultivation lessened the availability of rangelands, yet conflict between farmers and the Fulbe remained fairly well managed for a while (Guéye 1994). There was a smattering of disputes over crop damages when cattle strayed into Wolof fields, but the Fulbe adjusted their transhumance patterns to avoid this problem. Another source of contention was the cutting of the kinkeliba bush by Wolof and Serere women who wished to make a pleasant, non-caffeinated tea. However, cattle also find that plant pleasant, leading to a classic case of resource scarcity. As in the case of the Nigerian Ruga, local mechanisms and traditions of conflict management successfully contained the potential for widespread intergroup strife.

The potential for serious conflict was greatly heightened when the national government undertook a canal project to supply Dakar with drinking water. 
It became known that the Cayor canal would allow certain villages, including Fandéne, to receive water for irrigation, enabling cultivation to spread to arid zones like the Goll. Disputes arose when the Serere, who claimed the Goll, began to try and remove the Fulbe so that they could farm there. In addition, several agri-business representatives attempted to gain access to the Goll through the local Rural Council. Senegal's Rural Councils can allocate land in this way, and the Fandéne area Rural Council has allowed some outsiders to use the Goll land. The response of the local communities was to band together in opposition to the outsiders who were attempting to gain access to land in this area. The Fulbe, Serere, and Wolof of Fandéne thus were united in cooperation towards a common goal: preventing outsiders from gaining access to local land.

In the Fandéne village, the Fulbe and farmers prefer informal channels of settling disputes. In rural areas people tend to prefer customary law over modern law (Guéye 1994). Guéye (1994) further affirms the need for more enlightened legislation concerning pastoralist land rights in Senegal. He specifically notes that regulations concerning natural resource management need to be more amenable to the pastoralist production system and land use patterns. Senegal is similar to Nigeria in that the Senegalese land tenure laws consider traditional pastoral grazing lands as national land, and specify that cultivation of land is a necessary part of land ownership (Hoffman 1996).

The case of the Fandéne village reinforces the argument of theorists such as Wilson and Ellwood that Fulbe and farmer communities need to be able to control the land which they use, and regulate its use without external interference. External pressures and interference create pressure on the scarce natural resources and aggravate latent conflict.

\section{Ivory Coast and Cameroon}

Since its independence in 1960 the government of the Ivory Coast has pursued a capitalist and international market economy oriented strategy of economic development. The government has encouraged cash crop production for export and has invested in large sugar and palm oil complexes. In order to bolster its economic situation, the government has attempted 
to restrict imports of all kinds (specifically beef imports) from other West African countries whose prices were extremely variable, and from South America and West Europe whose prices were always high. To this end, it has adopted an official policy of encouraging Fulbe to migrate to this country and settle there. In keeping with the development models that sprung from the colonial era, the government also included a plan to sedentarise the Fulbe in this scheme. The migration of Fulbe into the region bolstered the national economy of the Ivory Coast by reducing their need for beef imports, but it has also resulted in serious conflict between Fulbe and local farmers (Bassett 1988; Harshbarger 1995).

Fulbe responded to the government's initiative, and to other pull factors such as high cattle prices in the Ivory Coast markets and the lack of taxes on cattle, by moving into this area. As Fulbe migrated to the Ivory Coast, disputes between the Fulbeherders and Senufo farmers began to occur. In the 1970s 'an unprecedented number of herds entered the northern savannah' (Bassett 1988:453). Due to the absence of historical ties between herding and farming in this area there is no tradition of farmers and Fulbe sharing compatible goals because of synergistic arrangements in their production styles. This makes the incidences of crop damage more important, as they do not constitute a necessary risk contained within the overall production framework.

Changes in the Senufo production style have made crop damage an especially significant phenomenon. In the past, Senufo farmers employed a lineagebased system of production that provided buffers against crop losses. Now, however, the conjugal household is the primary unit of production and major crop losses can inflict severe debts and the resulting personal mortification on Senufo farmers. In addition, the increases in monetisation and commodity production that resulted from the articulation with capitalism further increased the significance of crop damage to the Senufo. 'The expansion of cotton cultivation and the increasing monetisation of the local economy have also heightened farmers' awareness of the monetary value of their crops' (Bassett 1988:466). 
The conflict between these two groups became manifest and violent in the early 1980s as some Senufo began attacking and killing Fulbe. Ivory Coast politicians made inflammatory statements about the Fulbe presence in their country. Consequently, it gave the impression that these politicians and the government supported violence and thus encouraged the Senufo assaults (Bassett 1988; Harshbarger 1995). Many Fulbe migrated to the northern border of the Ivory Coast in order to flee from the violence.

On the other hand, Fulbe also began migrating south and west into the grasslands of Cameroon during the colonial period. This migration was encouraged by the British colonial government, who did not demand that farmers were compensated when crops were damaged by pastoralists. The presence of Fulbe herds, population growth, and the switch of many Cameroonian farmers from subsistence to commodity farming over the years led to major resource competition and conflict between farmers and herders. In the past five years there has been major conflict between Aghem and Meta farmers and Fulbe herders because of crop damages.

\section{Current attempts at farmer-herder conflict management in the Ivory Coast and Cameroon}

There are currently ongoing attempts to address the issue of crop damages caused by herd animals in both the Ivory Coast and Cameroon. In the Ivory Coast, crop damage committees have attempted to resolve disputes of this nature since the 1970s. The Farmer-Grazier Commission attempts to mediate between disputants in Cameroon. These institutions have generally failed to satisfy their mandate and enable farmers to be compensated, and have been ineffective as a means of managing farmer-Fulbe conflict (Bassett 1988; Harshbarger 1995).

There are several major problems that have been noted about these reactive approaches to farmer-herder conflict. One is that bribery and corruption are commonplace to both attempts; another is the time factor (Bassett 1988; Kum 1983 as cited in Harshbarger 1995). Time is a key element in dispute resolution, and 'slow access [to 'forums for dispute resolution'] is no access' (Nader \& Todd 1978:22-23). In the Ivory Coast, owners of damaged 
fields must travel to an administrative centre in order to begin the process of attempting to gain compensation. Unfortunately, the Farmer-Grazier Commission tends to delay cases, presumably often because of corruption (Kum 1983 as cited in Harshbarger 1995).

Nader and Todd (1978) further identify costs as an important element of the characteristics of forums for dispute resolution. The crop damage committees do not only require that field owners travel to administrative centres, which undoubtedly entails some expenses and loss of potential productivity, but they also stipulate that such plaintiffs must pay for the committee members' travel expenses (Bassett 1988)! These systems are simply not effective, and fail to diminish tensions between farmers and herders.

It is revealing that both of these systems are based on the model of adjudication (Harshbarger 1995). Adjudication refers to adversarial ways for dealing with conflict. These models tend to be non-participatory, and rely on third parties to unilaterally decide the outcome of the dispute. Adjudication occurs after a conflict has been manifested; it is generally not used to prevent them. Because these systems are adjudicative in nature, they are not set up to address the causes of crop damage - they merely exist in theory to rectify the effects of crop damage through compensation, and in practice they fail even in that.

\section{Conclusion: From analysis to mitigation}

Our analysis suggests that conflict between Fulbe and farmers has been heightened due to techno-environmental factors, particularly changes in production systems and land tenure regimes. These undermined the basis for cultivator-grazier complementarity and increased the potential for goal incompatibility and strife. Western interventions have exacerbated the root causes underlying the conflict situation, even when those efforts were purportedly aimed at improving living conditions for inhabitants of the subregion. Indeed, development and assistance projects have likely exacerbated farmer-Fulbe conflict in many cases. 
Before concluding, the policy implications of the points made here that underline the significance of analysis for conflict management practice or interventions must be considered as follows:

1. Western style land tenure policies have increased environmental degradation and have contributed to farmer-Fulbe goal incompatibility. Legislation that potentially aggravates intercommunal tensions, therefore, should be revised. Future legislation should consider the relationship between farming groups and Fulbe and avoid benefiting one group at the expense of the other.

2. Fulbe and farming groups are capable of effectively managing resources and cooperating for mutual benefit. Local control of natural resources and land is an important factor in making such cooperation possible.

3. Top-down, formalist, retributive and adjudicative approaches to managing conflict have been ineffective in Cameroon, the Ivory Coast, and Senegal. Such approaches were generally derived from Western models and have frequently failed to effectively address farmer-Fulbe disputes.

4. Communities in areas with a history of farmer-herder interaction developed strategies for conflict mitigation. These could provide context-appropriate conflict management institutions and should be investigated and reinvigorated or supported when feasible and desirable.

Taken together the above points suggest that in terms of policymaking, paternalistic, directive interventions should be abandoned in favour of a more supportive engagement that strives to draw on and build up local resources and capacities. A first step toward preventing and mitigating farmer-herder conflict may, ergo, be to agitate for more local control of resources. In addition, another significant task is the revision of laws that are biased against pastoralists and promote their marginalisation. Although 
less common, legislation and conditions that disadvantage horticulturalists are equally problematic.

Recent innovations in the fields of rangeland management, development, and pastoralist studies should be incorporated into policymaking. These theories are generally more appreciative of autochthonous or local methods of production, rangeland management and land tenure than previous paradigms. While they have garnered much attention, particularly among scholars, and despite some laudable efforts such as the Campfire project, there has been more discussion than action and the standard top-down approach remains influential. Governments, international organisations, and other actors in the Sahel have continued promoting ecologically questionable production styles, cash-crop plantations and settled agriculture on rangelands (Jacobsen 1988). Grazier mobility should be recognised as a viable production strategy and coercive sedentarisation should be abandoned. Policies should aim to increase the options and decision-making capacity of producers.

There have been many recent calls to develop new bottom-up methods of conflict resolution. Farmer-herder conflict mitigation would certainly be enhanced by the availability of effective methods of dispute settlement. There should be more exploration of local practices that could be utilised to help develop (and in some cases restore) local and grassroots type of mechanisms based on a 'win-win' approach to conflict. The populations in southern areas that have experienced relatively recent influxes of Fulbe could be introduced to the types of dispute management processes long used in the north and be trained in them, for instance. The lessons learned from such projects could be useful to the wider field of development and assistance, which has struggled with the need to effectively engage local practices and conflict management approaches.

In summation, farmer-herder conflicts are sometimes portrayed as one of the many plagues afflicting the 'poor, unfortunate' African continent. Such perspectives overlook the historical and structural processes that have heightened the potential of intercommunal strife. As is generally true, a state 
of positive peace or sustainable coexistence between these disparate groups is by no means impossible. Diagnosis or recognition of the factors influencing the current situation is the first step towards correcting misinformed views and enabling conflict prevention and mitigation. Hopefully the analysis of Fulbe-farmer disputes in this paper will make a modest contribution in that direction.

\section{Sources}

Baier, S. 1976. Economic History and Development: Drought and the Sahelian Economies of Niger. African Economic History 1, 1-16.

Bassett, T.J. 1988. The Political Ecology of Peasant-Herder Conflicts in the Northern Ivory Coast. Association of American Geographers Annals 78 (3), 453-472.

Bates, D. 1971. The Role of the State in Peasant-Nomad Mutualism. Anthropological Quarterly 44 (3), 109-131.

Behnke, R.H. \& Scones, I. 1992. Rethinking Range Ecology: Implications for Rangeland Management in Africa. Environment Working Paper 53, The World Bank, Sector Policy and Research Staff.

Bonfiglioli, A. 1992. Pastoralists at a Crossroads: Survival and Development Issues African Pastoralism. Nairobi: UNICEF/UNSO, Project for Nomadic Pastoralists in Africa.

Elbow, K. \& Rochegude, A. 1989. A Layman's Guide to the Forest Codes and ForestRelated Land Laws of Niger, Mali, and Senegal. Land Tenure Center paper, Univ. of Wisconsin-Madison.

Ellis, J.E. \& Swift, D.M. 1988. Stability of African pastoral ecosystems: Alternate paradigms and implications for development. Journal of Range Management 41 (6), 450-459.

Ellwood, W. 1995. Nomads at the Crossroads. New Internationalist 266. <http://www. newint.org/issue266/keynote.htm>

Forde, D. 1960. The Cultural Map of West Africa: Successive Adaptations to Tropical Forests and Grasslands, in Ottenberg, S. \& Ottenberg, P. (eds), Cultures and Societies of Africa, 116-138. New York: Random House.

Frantz, C. 1975. Pastoral Societies, Stratification, and National Integration in Africa. The Scandinavian Institute of African Studies Research Report 30. Uppsala: Uppsala Offset Center.

Fratkin, E., Galvin, K. \& Roth, E. (eds) 1994. African Pastoralist Systems: An Integrated Approach. Boulder: Lynne Rienner.

Freudenberger, K.S. 1995. Don't fence me in. New Internationalist 266. <http://www. newint.org/issue266/fence.htm>

Galaty, J.G. 1994. Rangeland Tenure and Pastoralism in Africa, in Fratkin et al 1994:91-112. 
Galaty, J.G. \& Johnson, D.L. 1990. The World of Pastoralism. New York, London: The Guilford Press.

Gallais, J. 1979. La situation de l'élevage bovine et le probléme des éleveurs en Afrique occidentale et centrale. Cahiers d'Outre Met 126, 113-138.

Galvin, K. A. 1992. Nutritional Ecology of Pastoralists in Dry Tropical Africa. American Journal of Human Biology 4, 209-221.

Gefu, J. 1992. Pastoralist Perspectives in Nigeria: The Fulbe of Udobo Grazing Reserve. The Scandinavian Institute of African Studies Research Report 89. Uppsala: Uppsala Offset Center.

Gilles, J.L. \& Gefu, J. 1990. Nomads, Ranchers, and the State: The Sociocultural Aspects of Pastoralism, in Galaty, J. \& Johnson, D. (eds), The World of Pastoralism. New York, London: The Guilford Press.

Grantz, Michael H. (ed) 1976. The Politics of Natural Disasters: The Case of the Sahel Drought. New York: Praeger.

Guéye, M.B. 1994. Conflicts and Alliances between Farmers and Herders: A Case Study of the 'Goll' of Fandéne Village. Senegal Paper 49, Drylands Network Programme. London: International Institute for Environment and Development.

Hardin, G. 1968. The Tragedy of the Commons. Science 162, 1243-1248.

Harshbarger, C. L. 1995. Farmer-Herder Conflict and State Legitimacy in Cameroon. Ph.D. diss., Univ. of Florida.

Hjort, A. 1982. A Critique of 'Ecological' Models of Pastoral Land Use. Nomadic People $10,11-27$.

Hoffman, I. 1996. Session 2 Comments. Electronic conference on Addressing Natural Resource Conflicts through Community Forestry. Forests, Trees, and People Programme, Forestry Division, Food and Agriculture Organization of the United Nations. Rome, Italy, January-April 1996.

Jacobsen, J.L. 1988. Environmental Refugees: A Yardstick of Habitability. Worldwatch Paper 86. Washington D.C.: Worldwatch Institute.

Kum, J.S.E. 1983. The farmer-grazier dispute in Aghem: An ethnic or an economic problem? Thesis, University of Yaoundé.

Lane, C. 1996. Opening Statement. Electronic conference on Addressing Natural Resource Conflicts through Community Forestry. Forests, Trees, and People Programme, Forestry Division, Food and Agriculture Organization of the United Nations. Rome, Italy, January-April 1996.

Lovejoy, P.E. \& Baier, S. 1976. Desert-Side Economy of the Central Sudan, in Grantz, Michael H. (ed), The Politics of Natural Disasters: The Case of the Sahel Drought, ed. Michael H. Grantz, 145-175. New York: Praeger.

Miller, P. 2007. Fulani. Grolier Multimedia Encyclopedia. Grolier Online <http://0-gme. grolier.com.novacat.nova.edu:80/cgi-bin/article?assetid=0114010-0> Accessed on 16 Aug 2007.

Mortimore, M. 1989. Adapting to Drought: Farmers, Famines and Desertification in West Africa. Cambridge: Cambridge University Press. 
Nader, L. \& Todd, H. 1978. The Disputing Process: Law in Ten Societies. New York: Columbia University Press.

Picardi, A.C. \& Seifert, W.W. 1976. A Tragedy of the Commons in the Sahel. Technology Review May, 42-51.

Shepherd, G. 8 February 1996. Public communication. Electronic conference on Addressing Natural Resource Conflicts through Community Forestry. Forests, Trees, and People Programme, Forestry Division, Food and Agriculture Organization of the United Nations. Rome, Italy, January-April 1996.

Sinclair, A.R.E. \& Fryxell, J.M. 1985. The Sahel of Africa: Ecology of a Disaster. Canadian Journal of Zoology 1985 (63), 989-994.

Traore, S. \& Lo, H. 1996. Natural Resource Conflicts and Community Forestry: A West African Perspective. Electronic conference on Addressing Natural Resource Conflicts through Community Forestry. Forests, Trees, and People Programme, Forestry Division, Food and Agriculture Organization of the United Nations. Rome, Italy, January-April 1996.

United States Agency for International Development (USAID) 1996. FEWS Bulletin, March $25^{\text {th }}$.

Unruh, J.D. 1990. Integration of Transhumant Pastoralism and Irrigated Agriculture in Semi-Arid East Africa. Human Ecology: An Interdisciplinary Journal 18(3), 223-246.

Van den Brink, Roger, Bromley, Daniel W. \& Chavas, Jean Paul 1995. The Economics of Cain and Abel: Agro-pastoral property rights in the Sahel. The Journal of Development Studies 31 (3), 373.

Waller, R. \& Sobania, N.W. 1994. Pastoralism in Historical Perspective, in Fratkin et al, 45-68.

Wilson, W. 1984. Resource Management in a Stratified Fulani Community. Ph.D. diss., Howard University.

World Bank Overseas Evaluation Department. 1994. Livestock in Africa: Support for Pastoralists. OED Précis, No. 65. 
